\title{
PENGARUH LAMA PERENDAMAN DAGING ITIK AFKIR PADA EKSTRAK KULIT BUAH CARICA (CARICA CANDAMARCENSIS) TERHADAP KEEMPUKAN DAN SUSUT MASAK DAGING
}

\section{THE EFFECT OF SOAKING TIME OF SPENT DUCK MEAT IN CARICA PEEL JUICE (CARICA CANDAMARCENSIS) ON TENDERNESS AND COOKING LOSSES OF MEATS}

\author{
S Setyo Prayitno1a, J Sumarmono, A Hantoro Djoko Rahardjo
}

${ }^{1}$ Programstudi Peternakan Fakultas Peternakan Universitas Jenderal Soedirman, Jl. Dr. Soeparno Karangwangkal, Purwokerto, Jawa Tengah

aKorespondensi: Salvian Setyo Prayitno, E-mail : salviansetyoo@gmail.com

\begin{abstract}
The purpose of this research was to study the effect of soaking time of spent duck meat in carica peel juice on tenderness and cooking losses of meats. The material used is 96 weeks old of spent female Tegal duck as many as 10 birds and 4 kilograms of carica peel. The research method was done experimentally, using a Completely Randomized Design (CRD). The treatments were soaking spent duck breast meat in $20 \%$ of carica peel juice for 0 minutes $\left(1\right.$ second) $\left(\mathrm{P}_{0}\right), 30$ minutes $\left(\mathrm{P}_{1}\right), 60$ minutes $\left(\mathrm{P}_{2}\right)$, and 90 minutes $\left(\mathrm{P}_{3}\right)$. Variables measured were tenderness and cooking losses of meats. The average of tenderness of treatments $\mathrm{P}_{0}, \mathrm{P}_{1}, \mathrm{P}_{2}$, and $\mathrm{P}_{3}$ were $0.0353,0.0434 ; 0.0504$; and 0.0560 $\mathrm{mm} / \mathrm{g} / \mathrm{sec}$. The average cooking losses for $\mathrm{P}_{0}, \mathrm{P}_{1}, \mathrm{P}_{2}$, and $\mathrm{P}_{3}$ were $32,53 \%$; 33.65\%; 34.77\%; and $35.86 \%$. Soaking time of the spent duck meat in carica peel juice of $20 \%$ concentration was very significant $(\mathrm{P}<0,01)$ on tenderness and cooking losses of meats. The soaking of spent duck meats in $20 \%$ concentration of carica peel juice for 90 minutes produce the meat tender meat, however the cooking losses was also high is that $35,86 \%$.
\end{abstract}

Keywords : spent duck meat, carica peel, tenderness, cooking losses

\begin{abstract}
ABSTRAK
Penelitian ini bertujuan untuk mengetahui pengaruh lama perendaman daging itik afkir pada ekstrak kulit buah carica terhadap keempukan dan susut masak daging. Materi yang digunakan adalah itik Tegal betina afkir umur 96 minggu sebanyak 10 ekor dan kulit buah carica sebanyak $4 \mathrm{~kg}$. Metode penelitian dilakukan secara eksperimental, menggunakan Rancangan Acak Lengkap (RAL). Perlakuan yang diuji adalah daging dada itik afkir direndam pada ekstrak kulit buah carica $20 \%$ selama 0 menit (1 detik) $\left(\mathrm{P}_{0}\right), 30$ menit $\left(\mathrm{P}_{1}\right), 60$ menit $\left(\mathrm{P}_{2}\right)$, dan 90 menit $\left(\mathrm{P}_{3}\right)$. Variabel yang diukur adalah keempukan dan susut masak daging. Hasil penelitian menghasilkan rataan keempukan daging dari perlakuan $\mathrm{P}_{0}, \mathrm{P}_{1}, \mathrm{P}_{2}$, dan $\mathrm{P}_{3}$ masing-masing adalah 0,$0353 ; 0,0434 ; 0,0504 ;$ dan $0,0560 \mathrm{~mm} / \mathrm{g} /$ detik. Rataan susut masak daging dari perlakuan $\mathrm{P}_{0}, \mathrm{P}_{1}, \mathrm{P}_{2}$, dan $\mathrm{P}_{3}$, masing-masing adalah 32,53\%; 33,65\%; 34,77\%; dan 35,86\%. Perendaman daging itik afkir pada ekstrak kulit buah carica dengan konsentrasi $20 \%$ berpengaruh sangat nyata $(\mathrm{P}<0,01)$ terhadap keempukan dan susut masak daging. Perendaman daging itik petelur afkir menggunakan ekstrak kulit buah carica $20 \%$ dengan lama waktu perendaman 90 menit menghasilkan daging yang lebih empuk, namun menghasilkan susut masak yang tinggi yaitu $35,86 \%$.

Kata Kunci : daging itik afkir, kulit buah carica, keempukan, susut masak
\end{abstract}


S Setyo Prayitno, J Sumarmono, A Hantoro Djoko Rahadjo. 2020. Pengaruh Lama Perendaman Daging Itik Afkir Pada Ekstrak Kulit Buah Carica (Carica Candamarcensis) Terhadap Keempukan Dan Susut Masak Daging. Jurnal Peternakan Nusantara 6(1): 15-.

\section{PENDAHULUAN}

Daging itik merupakan salah satu sumber protein hewani yang didapat dari unggas dan berguna untuk memenuhi kebutuhan manusia. Daging itik afkir di Indonesia kurang diminati masyarakat karena dagingnya yang alot dan memiliki aroma yang amis. Kendala tersebut membuat daging itik afkir belum bisa dimanfaatkan secara optimal. Pemanfaatan daging itik afkir untuk dikonsumsi bertujuan untuk meningkatkan nilai guna daging itik afkir yang nilai ekonomisnya masih rendah.

Metode pengempukan daging yang telah terbukti mampu mengempukkan daging yaitu dengan penggunaan enzim (Setyawardani dan Haryoko, 2005). Salah satu enzim yang mampu meningkatkan keempukan daging adalah enzim papain. Enzim papain adalah enzim yang dapat ditemui pada hampir seluruh bagian tanaman pepaya (Joanne et al., 2015).

Enzim papain juga mampu mempengaruhi susut masak daging. Menurut Suradi (2006) protein daging dapat terdenaturasi akibat penambahan enzim protease sehingga diikuti dengan kehilangan kemampuan protein untuk mengikat air yang pada akhirnya semakin besarnya susut masak. Enzim papain juga dapat ditemui pada tanaman yang masih satu famili dengan tanaman pepaya (Joanne et al.,, 2015).

Buah carica (Carica candamarcensis) merupakan jenis buah pepaya yang tumbuh di dataran tinggi dan masih termasuk satu family dengan buah papaya pada umumnya. Hampir seluruh bagian tanaman carica mengandung enzim papain, terutama pada bagian kulitnya. Enzim papain merupakan enzim protease yang terkandung dalam getah papaya dan mampu memecah rantai panjang molekul protein menjadi molekul-molekul yang lebih kecil (Budiman, 2016).

Kulit buah carica memiliki nilai ekonomis yang rendah sehingga masih belum dimanfaatkan secara optimal. Kulit buah carica yang mengandung enzim papain dapat digunakan sebagai bahan pengempuk daging. Salah satu cara penggunaannya adalah dengan membuatnya menjadi ekstrak kulit buah carica. Proses pembuatan ekstrak kulit buah carica diharapkan mampu meningkatkan potensi penggunaan kulit buah carica dan sekaligus meningkatkan potensi penggunaan daging itik afkir sehingga memenuhi kebutuhan gizi dan menarik konsumen. Penelitian ini bertujuan untuk mengetahui pengaruh lama perendaman daging itik afkir pada ekstrak kulit buah carica dengan konsentrasi 20\% terhadap keempukan dan susut masak daging.

\section{MATERI DAN METODE}

\section{Materi}

Penelitian dilaksanakan pada bulan Februari 2018. Bertempat di Laboratorium Teknologi Hasil Ternak, Fakultas Peternakan, Universitas Jenderal Soedirman. Bahan yang digunakan dalam penelitian ini adalah itik petelur afkir umur 96 minggu sebanyak 10 ekor, kulit buah carica sebanyak $4 \mathrm{~kg}$ dan akuades 8 liter. Peralatan yang digunakan dalam penelitian yaitu penetrometer, blender, kompor, panci, pisau, baskom kecil, thermometer, $\mathrm{pH}$ meter, timbangan analitik, plastik bening, dan benang kasur.

\section{Rancangan percobaan}

Rancangan penelitian yang digunakan adalah rancangan acak lengkap (RAL) dengan empat perlakuan dan lima kali ulangan. Sehingga terdapat 20 unit percobaan yang digunakan dalam penelitian.

\section{Perlakuan}

Perlakuan dalam penelitian ini yaitu sebagai berikut: $\mathrm{P}_{0}$ : daging dada itik afkir direndam pada ekstrak kulit buah carica $20 \%$ selama 0 menit (1 detik). $\mathrm{P}_{1}$ : daging dada itik afkir direndam pada ekstrak kulit buah carica $20 \%$ selama 30 menit. $\mathrm{P}_{2}$ : daging dada itik afkir direndam pada ekstrak kulit buah carica 20\% selama 60 menit. $\mathrm{P}_{3}$ : : daging dada itik afkir direndam pada ekstrak kulit buah carica 20\% selama 90 menit.

\section{Prosedur pelaksanaan penelitian}

Pembuatan ekstrak kulit buah carica $\mathbf{2 0 \%}$, proses pembuatan ekstrak kulit buah carica diawali dengan membersihkan kulit buah 
carica dari kotoran yang menempel. Kulit buah carica yang digunakan dalam penelitian ini adalah kulit buah carica muda sebanyak $4 \mathrm{~kg}$. Kulit buah carica yang sudah bersih kemudian di blender hingga halus lalu disaring, sehingga terpisah antara sari kulit buah carica dengan ampasnya dan diambil air sari kulit buah carica. Pembuatan larutan perendaman dilakukan dengan cara menambahkan $20 \%$ air sari kulit buah carica dengan $80 \%$ akuades dari total 500 $\mathrm{ml}$ larutan perendaman (100 ml sari kulit carica $+400 \mathrm{ml}$ akuades).

Perendaman daging itik afkir, daging itik afkir yang digunakan adalah itik Tegal betina afkir umur 96 minggu sebanyak 10 ekor. Bagian daging itik yang digunakan adalah daging itik $1 / 2$ bagian dada (fillet) yang sudah di diamkan selama 1 jam setelah pemotongan. Selanjutnya daging itik $1 / 2$ bagian dada direndam pada ekstrak kulit buah carica $20 \%$ selama 0 menit (1 detik) $\left(\mathrm{P}_{0}\right), 30$ menit $\left(\mathrm{P}_{1}\right), 60$ menit $\left(\mathrm{P}_{2}\right)$, dan 90 menit $\left(\mathrm{P}_{3}\right)$. Daging yang sudah direndam selanjutnya ditiriskan selama \pm 5 menit.

Pengukuran keempukan dan susut masak daging, susut masak daging itik afkir diukur dengan menggunakan metode CSIRO, daging itik afkir dipotong sebanyak 10 gram kemudian dimasukan ke dalam plastik dan diikat. Selanjutnya daging direbus selama 30 menit pada suhu $80^{\circ} \mathrm{C}$ dan ditimbang sebagai bobot akhir daging. Keempukan daging itik afkir diukur dengan menggunakan alat penetrometer. Daging itik afkir yang digunakan untuk mengukur keempukan adalah daging dari hasil pengukuran susut masak. Daging dipotong dengan ukuran $\left(1 \times 1 \times 1 \mathrm{~cm}^{3}\right)$ dan selanjutnya dilakukan pengukuran dengan penetrometer. Data yang diperoleh kemudian dianalisis statistik menggunakan analisis variansi dan diuji lanjut menggunakan uji orthogonal polynomial (Steel dan Torrie, 1993).

\section{Peubah yang diamati}

Peubah yang diamati dalam penelitian ini adalah keempukan $(\mathrm{mm} / \mathrm{g} / \mathrm{t})$ dan susut masak (\%) daging dada itik afkir. Keempukan daging merupakan pengujian kualitas daging berdasarkan kemudahan dalam menembus serat daging. Susut masak daging adalah banyak sedikitnya air yang hilang dari dalam daging akibat pemasakan.

\section{Analisis Data}

Data yang diperoleh dalam penelitian ditabulasikan dalam tabel tabulasi data dan dianalisis menggunakan analisis variansi (ANOVA). Hasil analisis kemudian dilanjutkan dengan menggunakan Uji Orthogonal Polynomial dengan bantuan program SPSS 16.

\section{HASIL DAN PEMBAHASAN}

\section{Keempukan daging}

Keempukan daging dada itik afkir sangat dipengaruhi oleh lama waktu perendaman $(\mathrm{P}<0,01)$ (Tabel 1). Secara umum, semakin lama waktu perendaman maka keempukan daging itik afkir semakin tinggi. Rataan keempukan daging itik afkir terendah diperoleh pada waktu 0 menit (P0) yaitu $0,0353 \mathrm{~mm} / \mathrm{g} /$ detik dan tertinggi pada waktu 90 menit (P3) yaitu 0,0560 $\mathrm{mm} / \mathrm{g} /$ detik. Hasil data pengukuran keempukan daging itik afkir yang direndam pada ekstrak kulit carica $20 \%$ dengan lama perendaman 0 , 30, 60, dan 90 menit dapat dilihat pada Tabel 1 .

Tabel 1 Hasil keempukan daging itik afkir yang direndam pada ekstrak kulit carica $20 \%$ dengan lama waktu perendaman yang berbeda.

\begin{tabular}{cc}
\hline Perlakuan & $\begin{array}{c}\text { Keempukan } \\
(\mathbf{m m} / \mathbf{g} / \mathbf{d e t i k})( \pm \mathbf{S d})\end{array}$ \\
\hline $\mathrm{P}_{0}$ & $0,0353 \pm 0,0042$ \\
$\mathrm{P}_{1}$ & $0,0434 \pm 0,0038$ \\
$\mathrm{P}_{2}$ & $0,0504 \pm 0,0019$ \\
$\mathrm{P}_{3}$ & $0,0560 \pm 0,0024$ \\
\hline Rataan \pm Sd & $0.0463 \pm 0.0031$ \\
\hline
\end{tabular}

Keterangan : P0 : daging direndam selama 0 menit (1 detik), P1 : daging direndam selama 30 menit, P2 : daging direndam selama 60 menit, dan P3 : daging direndam selama 90 menit.

Lama perendaman yang berbeda berpengaruh sangat nyata terhadap keempukan daging dada itik afkir $(\mathrm{P}<0,01)$. Hal tersebut disebabkan adanya pengaruh enzim papain pada kulit buah carica, dan enzim tersebut biasa digunakan sebagai bahan pengempuk daging. Hal tersebut didukung dengan pendapat Soeparno (1998) bahwa keempukan daging dipengaruhi oleh beberapa faktor, yaitu faktor sebelum dan sesudah pemotongan, Faktor setelah pemotongan (postmortem) meliputi pelayuan, pembekuan, metode pengolahan, dan penambahan bahan pengempuk. 


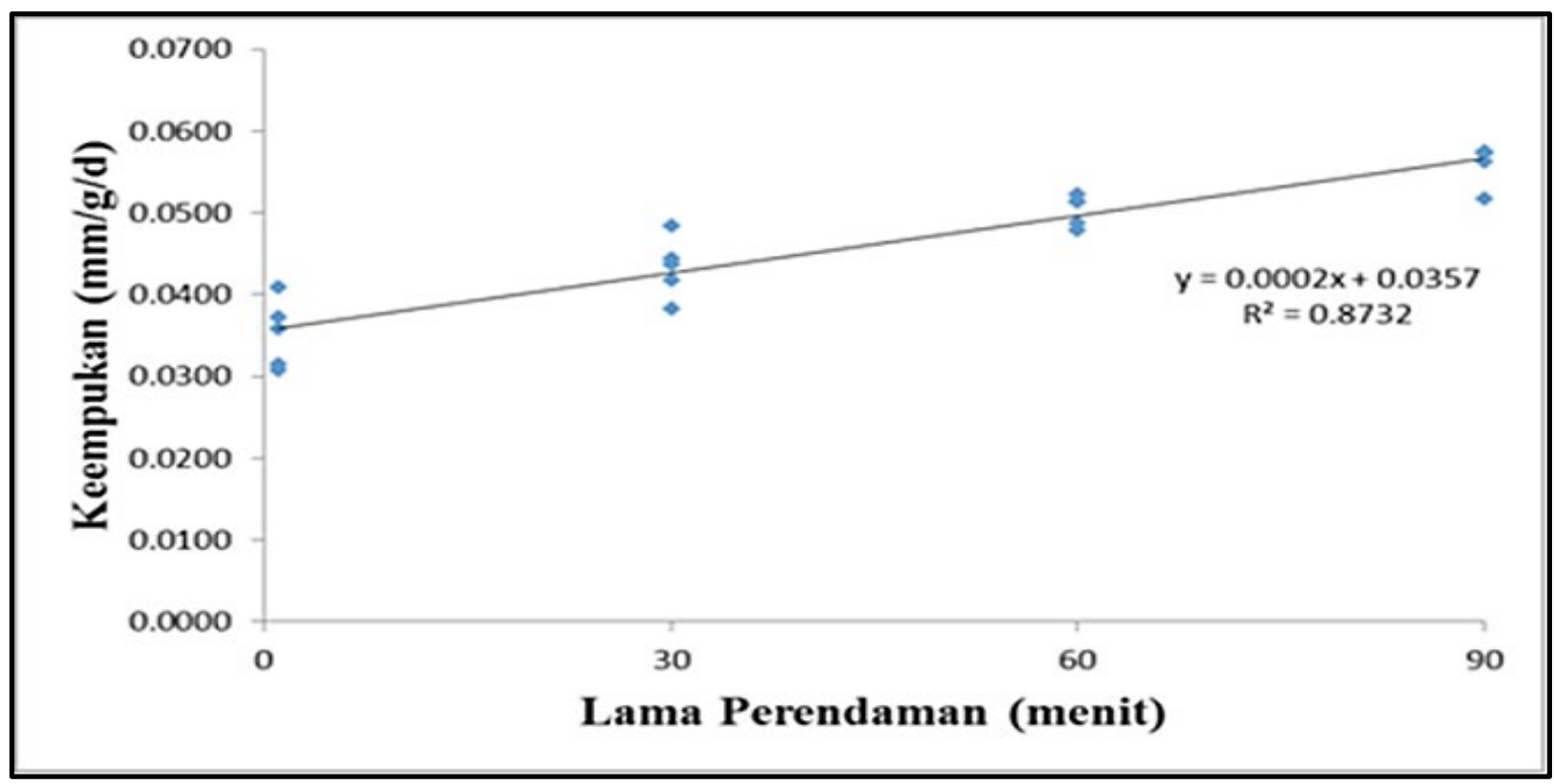

Gambar 1. Grafik keempukan daging dada itik afkir yang direndam pada ekstrak kulit carica 20\% dengan lama perendaman yang berbeda.

Nilai keempukan daging dada itik afkir terus meningkat secara linier dengan bertambahnya lama waktu perendaman menggunakan ekstrak kulit carica 20\%. (Gambar 1). Hal tersebut diduga karena kulit buah carica mengandung enzim papain yang mampu menghidrolisis jaringan ikat daging sehingga nilai keempukan daging meningkat. Hal tersebut sesuai dengan pendapat Silaban dkk (2012) bahwa enzim papain adalah golongan enzim proteolitik yang terkandung dalam getah pepaya dan memiliki kemampuan memecah molekul protein, sehingga biasa digunakan sebagai bahan mengempukkan daging. Menurut Lawrie (2003) enzim proteolitik akan merusak mukopolisakarida dari matriks subtansi dasar, sehingga akan menurunkan serat-serat tenunan pengikat, selama proses ini kolagen dan myofibril terhidrolisis, hal ini menyebabkan hilangnya ikatan antar serat daging dan juga serat fragmen menjadi lebih pendek, sehingga sifat serat otot lebih mudah terpisah dan menjadikan daging semakin empuk.

Bertambahnya lama waktu peredaman akan membuat daging itik menjadi semakin empuk. Hal tersebut diduga semakin lama waktu perendaman daging akan menyebabkan semakin banyak protein daging yang terhidrolisis akibat pengaruh enzim papain. Hal tersebut sejalan dengan pendapat Afrila dan Santoso (2011) bahwa semakin lama perendaman daging pada enzim proteolitik, maka akan memberikan waktu yang lebih lama bagi enzim proteolitik untuk bekerja dalam menghidrolisis protein. Winarno (1995) menambahkan bahwa sistem kerja enzim dipengaruhi oleh waktu, konsentrasi enzim, cara kerja enzim, dan suhu.

\section{Susut Masak Daging}

Susut masak daging dada itik afkir sangat dipengaruhi oleh lama waktu perendaman $(\mathrm{P}<0,01)$ (Tabel 2). Secara umum, semakin lama waktu perendaman maka susut masak daging itik afkir semakin tinggi. Rataan susut masak daging itik afkir terendah diperoleh pada waktu 0 menit $\left(\mathrm{P}_{0}\right)$ yaitu $32,53 \%$ dan tertinggi pada waktu 90 menit $\left(\mathrm{P}_{3}\right)$ yaitu $35,86 \%$.

Tabel 2 Hasil susut masak daging itik afkir yang direndam pada ekstrak kulit carica $20 \%$ dengan lama waktu perendaman yang berbeda.

\begin{tabular}{cc}
\hline Perlakuan & $\begin{array}{c}\text { Susut Masak } \\
(\mathbf{\%})( \pm \text { Sd) }\end{array}$ \\
\hline $\mathrm{P}_{0}$ & $32,53 \pm 0,61$ \\
$\mathrm{P}_{1}$ & $33,65 \pm 0,49$ \\
$\mathrm{P}_{2}$ & $34,77 \pm 0,29$ \\
$\mathrm{P}_{3}$ & $35,86 \pm 0,42$ \\
\hline Rataan \pm Sd & $34.20 \pm 0,45$ \\
\hline
\end{tabular}

Keterangan : P0 : daging direndam selama 0 menit (1 detik), P1 : daging direndam selama 30 menit, P2 : daging direndam selama 60 menit, dan P3 : daging direndam selama 90 menit. 
Lama perendaman yang berbeda berpengaruh sangat nyata terhadap susut masak daging dada itik afkir $(\mathrm{P}<0,01)$. Hal tersebut diduga kulit buah carica mengandung enzim papain, yang merupakan golongan enzim proteolitik, sehingga semakin lama waktu perendaman, maka akan memberikan waktu yang lebih lama untuk memutus rantai protein daging menjadi lebih sederhana dan akibatnya memberikan pengaruh terhadap susut masak daging. Menurut Lawrie (2003) susut masak daging dipengaruhi oleh jumlah protein daging, lama dan suhu pemasakan. Soeparno (1998) menambahkan bahwa pemasakan daging menyebabkan daging membengkak, kemudian mengkerut dan akhirnya mengalami disintegrasi, hal ini yang menyebabkan keluarnya air dalam daging.

Nilai susut masak daging dada itik afkir terus meningkat secara linier dengan bertambahnya lama waktu perendaman menggunakan ekstrak kulit carica 20\%. (Gambar 2). Hal tersebut diduga semakin lama waktu perendaman daging maka semakin memberikan waktu yang lebih lama bagi enzim papain untuk menghidrolisis protein daging, sehingga akan menurunkan kemampuan daging dalam mengikat air dan pada akhirnya nilai susut masak akan meningkat. Protein di dalam daging akan menahan jumlah air yang keluar dari dalam daging melalui serat-serat daging (Soeparno, 1998). Menurut Lawrie (2003) enzim proteolitik akan masuk ke dalam daging melalui serat-serat daging sehingga enzim akan merusak mukopolisakarida dari matriks subtansi dasar, selama proses ini protein daging akan terhidrolisis, hal tersebut menyebabkan menurunnya ikatan antar serat daging, akibatnya kemampuan protein daging dalam mengikat air berkurang, sehingga menyebabkan air didalam daging mudah keluar melalui seratserat daging dan mengakibatkan nilai susut masak daging tinggi.

Nilai susut masak daging yang baik adalah memiliki nilai yang rendah. Hal tersebut juga sejalan dengan pendapat Prayitno dkk (2010) bahwa semakin kecil persen susut masak maka semakin sedikit air yang hilang dan nutrien yang larut dalam air, begitu juga sebaliknya. Suradi (2006) juga menambahkan bahwa daging dengan nilai susut masak rendah mempunyai kualitas daging relatif lebih baik dari pada daging dengan nilai susut masak tinggi, karena kehilangan nutrisi selama pemasakan akan lebih sedikit. Namun, hasil rataan susut masak perendaman selama 90 menit $\left(\mathrm{P}_{3}\right)$ walaupun menghasilkan rataan susut masak yang paling tinggi yaitu $35,86 \%$, tetapi masih dalam taraf wajar atau masih dapat diterima. Hal tersebut didukung dengan pendapat Sopearno (1998) bahwa pada umumnya nilai susut masak daging bervariasi antara 1,5\%-54,5\%.

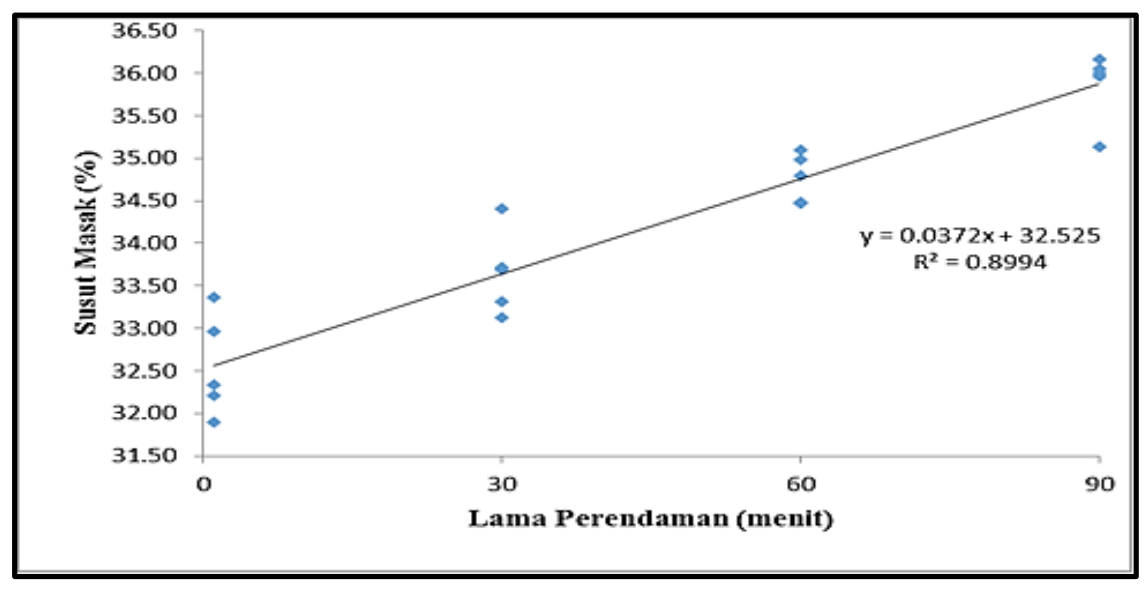

Gambar 2. Grafik susut masak daging dada itik afkir yang direndam pada lama perendaman yang berbeda 


\section{KESIMPULAN DAN IMPLIKASI}

\section{Kesimpulan}

Berdasarkan hasil penelitian, maka dapat disimpulkan bahwa semakin lama waktu perendaman daging dada itik petelur afkir dengan menggunakan ekstrak kulit buah carica 20\% akan meningkatkan keempukan dan susut masak daging. Perendaman daging dada itik petelur afkir menggunakan ekstrak kulit buah carica 20\% dengan lama waktu perendaman 90 menit menghasilkan daging yang lebih empuk, namun menghasilkan susut masak yang tinggi yaitu 35,86\%. Hasil rataan susut masak perendaman selama 90 menit walaupun menghasilkan susut masak yang paling tinggi yaitu $35,86 \%$, tetapi masih dalam taraf wajar atau masih dapat diterima.

\section{Implikasi}

Perlu juga dilakukan penelitian lebih lanjut tentang perendaman daging dada itik petelur afkir menggunakan ekstrak kulit buah carica dengan konsentrasi yang berbeda namun dengan waktu yang sama terhadap kualitas fisik dan uji organoleptik daging dada itik petelur afkir.

\section{DAFTAR PUSTAKA}

Afrila A, Santoso B. 2011. Water Holding Capacity, Kadar protein, dan Kadar Air Dendeng Sapi pada Berbagai Konsentrasi Ekstrak Jahe dan Lama Perendaman yang Berbeda. Jurnal Ilmu dan Teknologi Hasil Ternak. 6(2): 41-46.

Budiman F. 2016. Pengaruh Konsentrasi Enzim Papain (Carica Pepaya) dan Suhu Fermentasi Terhadap Karakteristik Crackers. [Skripsi] Prodi Teknologi Pangan. Fakultas Teknik Universitas Pasundan. Bandung.

Joanne A, Setiobudi CS, Wibisono R. 2015. Pemanfaatan Kulit Buah Pepaya Sebagai Manisan untuk Mengurangi Iritasi Lambung. Laporan Penelitian Ilmiah. Yayasan Widya Bhakti. Bandung.

Lawrie, R.A. 2003. Meat Science. Terjemahan: A. Parakkasi. Ilmu Daging Edisi Lima. Universitas Indonesia Press. Jakarta.
Nuhriawangsa, A.M.P. 2000. Pemanfaatan Pepaya Muda dan Daun Pepaya untuk Meningkatkan Kualitas Daging Itik Afkir. Laporan Hasil Penelitian. Fakultas Pertanian. Universitas Negeri Semarang. Semarang.

Prayitno AH, Suryanto E, Zuprizal. 2010. Kualitas Fisik dan Sensoris Daging Ayam Broiler yang Diberi Pakan dengan Penambahan Ampas Virgin Coconut Oil (VCO). Buletin Peternakan 34(1): 55-63.

Prissa E, Suswoyo I. Wasito S. 2014. Susut Masak dan pH Daging Itik Lokal Afkir Berdasarkan Sistem Pemeliharaan dan Lokasi yang Berbeda. Jurnal Ilmiah Peternakan. 2(1): 221-226.

Setyawardani T, Haryoko I. 2005. Kajian Metode Pengempukan Daging Kambing Tua. Journal Animal Production. 7(2): 106-110.

Silaban F, Panggabean FTM, Rahmadani Soripada TA. 2012. Kajian Pemanfaatanan Enzim Papain Getah Pepaya untuk Melunakan daging. Laporan Hasil Penelitian. Universitas Negeri Medan. Medan

Soeparno. 1998. Ilmu dan Teknologi Daging. Gadjah Mada University Press. Yogyakarta.

Steel RGD, Torrie JH. 1993. Prinsip dan Prosedur Statisktik. Terjemahan B. Soemantri. Gramedia. Jakarta.

Suradi K. 2006. Perubahan Fisik Daging Ayam Broiler Postmortem Selama Penyimpanan Temperatur Ruang. Jurnal Ilmu Ternak. 6(1): 23-27.

Winarno F.G. 1995. Enzim Pangan. PT. Gramedia Pustaka Utama. Jakarta. 